\title{
O currículo entre o relativismo e o universalismo: Dialogando com Jean-Claude Forquin*
}

Vera Maria Candau**

\begin{abstract}
RESUMO: O texto analisa criticamente as principais idéias apresentadas por Forquin, ressaltando suas contribuições mais relevantes e levantando questões relacionadas principalmente à tensão entre universalismo e relativismo no processo de seleção dos conteúdos escolares e às implicações do multiculturalismo para a escolarização hoje.
\end{abstract}

Palavras-chave: Currículo, saber escolar, conhecimento universal, diversidade cultural

\section{A relevância do tema}

O primeiro comentário que gostaria de fazer em relação ao texto do professor Forquin relaciona-se com a relevância do tema. As questões que o texto aborda são de grande atualidade e importância para o debate atual sobre educação escolar: a natureza e justificação do que é ensinado nas escolas, a contraposição entre os princípios de universalismo e relativismo em suas diferentes modalidades e sua incidência sobre esta problemática, as relações entre multiculturalismo e educação, entre outras.

* Texto apresentado no seminário internacional A Construção da Educação Brasileira, promovido pela Faculdade de Educação da UFRJ, Rio de Janeiro, 1997.

** Professora do Departamento de Educação/PUC-RJ. E-mail: umfc@edu.puc-rio.br. 
A reflexão e o debate sobre estes temas estão emergindo cada vez com maior força entre nós, com configurações específicas. A problemática suscitada pela elaboração dos Parâmetros Curriculares Nacionais (PCNs) tem constituído uma ocasião privilegiada de confronto entre diferentes posições e tendências. Neste contexto, as posições mais universalistas e aquelas mais sensíveis à problemática da diversidade cultural se têm explicitado claramente. Convém também salientar que, pela primeira vez em nosso país, uma proposta curricular de caráter nacional inclui, neste caso na categoria de "tema transversal", a temática da diversidade cultural.

No entanto, chama a atenção no texto do professor Forquin a ausência de referências a autores como Michael Apple, Henry Giroux, Peter McLaren, Gimeno Sacristán, entre outros representantes da chamada pedagogia crítica, cujas contribuições têm tido um significativo impacto na produção brasileira da área e que não aparecem como interlocutores do texto, o que evidencia universos acadêmicos e intelectuais de referência diferenciados.

\section{A questão do universalismo e suas implicações para o processo de escolarização}

O professor Forquin parte de algumas afirmações que consideramos fundamentais para compreendermos seu pensamento:

- a vocação universalista, constitutiva da própria modernidade, está presente na instituição escolar, tanto do ponto de vista do seu funcionamento, assim como aos conteúdos incluídos no processo de ensino;

- os conteúdos de ensino veiculados pela escola se inserem na esfera dos "saberes públicos", dotados de alto nível de generalidade, potencialmente acessíveis a todos e que valem independentemente das circunstâncias e interesses particulares;

- estes "saberes públicos", os saberes escolares por excelência, se opõem tanto aos saberes iniciáticos e esotéricos, como aos saberes puramente práticos, que se comunicam vitalmente, ou triviais, ligados aos contextos ordinários de vida; trata-se de saberes essencialmente gerais, organizadores e integradores, destinados a "promover o acesso a conhecimentos precisos ou competências estruturalmente fundamentais"; a generalidade constitui o fundamento da universalidade destes saberes; 
- a escola está chamada a reconhecer indivíduos iguais em direitos e em deveres, abstraídos de suas pertenças coletivas e liberados de suas singularidades pessoais.

É consciente e se confronta com as objeções apresentadas pela crítica sociológica e política da escola desenvolvida principalmente a partir dos anos 60 pelos teóricos da reprodução na França, pela chamada "nova sociologia" inglesa, por diferentes trabalhos de sociologia empírica, entre outros que desvelam os processos de discriminação e desigualdade presentes nos processos de escolarização. No entanto, afirma com força o universalismo como "um ideal regulador e mobilizador" do universo escolar e parece expressar uma certa "naturalização" dos saberes escolares, especialmente em relação à escola fundamental.

No entanto, em nenhum momento do seu texto são explicitados os critérios de construção destes saberes universais. Não é esta uma construção histórica? Quem define estes "saberes públicos"? Através de que processos? Não será que o que muitas vezes consideramos "universal" constitui a universalização de saberes particulares, construídos a partir de bases etnocêntricas que se consideram portadoras de universalidade? Não será o universalismo um princípio referencial que deve ser continuamente questionado, repensado, ter dilatadas suas fronteiras sob pena de se cristalizar e se tornar anacrônico?

\section{A questão do multiculturalismo}

É interessante a distinção que é feita entre o sentido descritivo e prescritivo do multiculturalismo, assim como das duas maneiras de promover a opção multicultural na educação: a radical, separatista e defensiva, que defende formas diferenciadas de escolarização para grupos culturais diferenciados, e a que defende a interação e o encontro no interior da mesma escola de pessoas de diferentes identidades culturais. Também consideramos de especial relevância a explicitação da característica fundamental de um ensino que se pretenda multicultural, que, segundo Forquin, só se torna tal a partir do momento em que pressupõe certas escolhas pedagógicas que são, ao mesmo tempo, éticas ou políticas.

Em relação à versão interativa e aberta do multiculturalismo-interculturalismo, em relação à qual o autor apresenta uma valorização positiva, o texto afirma que coloca um grave problema pedagógico: saber a partir de 
que critérios se efetivarão a seleção e a justificativa dos conteúdos curriculares. - O que significa inserir no interior do currículo uma pluralidade de valores e referências culturais?

$\mathrm{Na}$ nossa opinião, questão semelhante pode ser colocada em relação ao universalismo. Neste caso, também os critérios utilizados têm de ser explicitados e seu caráter de universalidade verificado historicamente. As questões de seleção e justificação dos conteúdos curriculares não afetam somente as opções que se propõem incorporar à perspectiva multicultural. A posição universalista também está desafiada por esta problemática.

\section{Universalismo versus relativismo}

Esta é a questão fundamental que perpassa todo o texto. Forquin se confronta diretamente com ela. Afirma a sua complexidade, assim como a necessidade de fazer distinções: universalismo etnocêntrico e dominador, universalismo aberto e tolerante, relativismo radical, relativismo interativo...

No entanto, na nossa leitura, é clara sua inclinação universalista. Esta é a vocação da escola. É consciente de que, no contexto das sociedades multiculturais, a escola não pode ignorar a diversidade de sua clientela, no entanto afirma que, para que possa assegurar de maneira coerente seu papel de formação intelectual e de integração cívica e simbólica, deve repudiar a "tentação do relativismo". Sua posição é clara.

\section{Para Giroux,}

os/as educadores não poderão ignorar, no próximo século, as difíceis questões do multiculturalismo, da raça, da identidade, do poder, do conhecimento, da ética e do trabalho que, na verdade, as escolas já estão tendo de enfrentar. Essas questões exercem um papel importante na definição do significado e do propósito da escolarização, no que significa ensinar e na forma como os/as estudantes devem ser ensinados/as para viver num mundo que será amplamente mais globalizado, high tech e racialmente diverso que em qualquer época da história. (1995, p. 88)

A escola tem de se defrontar fortemente com esta realidade e repensar o processo de escolarização a partir destes desafios. Não se trata 
exclusivamente de um desafio analítico e conceitual, por mais importante que seja o aprofundamento nessa perspectiva. Trata-se de recriação do sentido profundo, de reinventar a escola. Acolhendo a tradição construída como histórica, evitando posições saudosistas e/ou fundamentalistas, para, conscientes das raízes, enfrentarmos as novas questões e recriarmos o sentido da escolarização.

Nessa perspectiva, consideramos importante assumirmos o desafio de trabalhar a tensão dialética entre universalismo e relativismo, entre igualdade e diferença. Não estaremos chamados a relativizar o universalismo, afirmando seu caráter histórico e dinâmico, e, ao mesmo tempo, a relativizar o relativismo, afirmando seu caráter não absoluto, atento aos "meta-valores", aos conteúdos transculturais, historicamente construídos?

Outra contribuição que nos parece relevante para trabalharmos nessa perspectiva é de Santos (1997, p. 122), sociólogo português, quando afirma a necessidade de articularmos políticas de igualdade e políticas de identidade, já que "as pessoas e os grupos sociais têm o direito a ser iguais quando a diferença os inferioriza e o direito a ser diferentes, quando a igualdade os descaracteriza". Não será este um dos grandes desafios da educação e, especificamente, da escola, hoje?

Recebido para publicação em Agosto de 2000.

The curriculum, between relativism and universalism:

A dialogue with Jean-Claude Forquin

ABSTRACT: This article critically analyzes the main ideas presented by Forquin, stressing his major contributions to curriculum studies today. It also raises questions about the tensions between universalism and relativism in selecting the content for curricula and the implications of multiculturalism in education today.

Key words: Curriculum, school-related knowledge, universal knowledge, cultural diversity

\section{Bibliografia}

GIROUX, H. "Praticando estudos culturais nas faculdades da educação". In: SILVA, T.T. (org.), Alienígenas na sala de aula. Rio de Janeiro: Vozes, 1995.

SANTOS, B. de S. "Uma concepção multicultural de direitos humanos", Lua Nova, n. 39, 1997. 